\title{
Quantification of bacteria in domestic water storage tanks in Sharjah
}

\author{
Ala H. Amiri, Ruwaya R. Alkendi, Yasser T. Ahmed \\ Faculty of Science, Department of Biology, United Arab Emirates University \\ Email address: \\ 200734525@uaeu.ac.ae(A. H. Amiri), ruwayaa@uaeu.ac.ae(R. R. Alkendi), Yasser.turki@uaeu.ac.ae(Y. T. Ahmed)
}

\section{To cite this article:}

Ala H. Amiri, Ruwaya R. Alkendi, Yasser T. Ahmed. Quantification of Bacteria in Domestic Water Storage Tanks in Sharjah. Journal of Water Resources and Ocean Science. Vol. 2, No. 5, 2013, pp. 125-132. doi: 10.11648/j.wros.20130205.20

\begin{abstract}
Maintaining the microbiological quality of water is an important means of preventing water-bornediseases. The aim of the present study was to use the Membrane Filter (MF) method to examine the level of coliforms (Escherichia coli)and total bacteria in water storage tanks fitted in different homes in Sharjah. The MF method can determine the presence or absence of bacteria within only 24 hours. A volume of $100 \mathrm{ml}$ of water sample is filtered through bacterial retaining membrane; the membrane is then transferred to a selective media and incubated for $24 \mathrm{~h}$ at $37 \square \mathrm{C}$ to enable the growth of the bacteria. On the growing plates, Total Bacterial Count (TBC) shows as yellow colonies, Total coliforms (TC)shows as dark red colonies and $E$. colishows as dark blue colonies. Eleven houses were sampled for along a period of six weeks. Samples were collected from two storage tank levels (ground level and roof top level) located in each house. The results showed that, although none of the samples contained E. coli, they did contain other coliforms. The absence of E.coli indicate no fecal contamination by animal and/or human, on the other hand, other Coliform bacteria were present in water which are usually introduced by the environment such as Klebsiella, Enterobacter spp., and Serratia. These isolates pose a health risk if they reach the human system. More than half of the samples collected (72.7\%) showed a high TBC $(>10 \mathrm{CFU} / 100 \mathrm{ml})$, which suggests further investigation is needed to examine the sources of contamination to the storage tanks. The bacterial contaminants found in the storage tanks usually come from the environment which may indicate the presence of other contaminants like chemical contaminants that are also found in the environment and entered via the same route to the storage tanks. The results of this study suggest the adoption of a cleaning system for the water tank at least twice a year to prevent accumulation of contaminants. In addition, the results suggest that chemical contaminants might be present in the water, therefore, chemical analysis is recommended.
\end{abstract}

Keywords: Fecal Coliform, Total Coliform, E. Coli, Membrane Filter Technique, Sharjah, Total Bacterial Count

\section{Introduction}

Unsafe drinking water, poor sanitation, and lack of hygiene are major causes of disease in both developed and developing nations. Water-borne diseases cause millions of deaths each year, mainly among children under 5 years-ofage [15]; however, many of these diseases are preventable. It is estimated that the global disease burden could be reduced by one-tenth simply byimproving water quality, sanitation, and personal hygiene [20].

A human being requires about 20 liters of freshwater every day to meet basic survival needs (drinking and cooking), and an additional 50 to 150 liters for washing, bathing, laundry, irrigation etc. As the global population and overall living standards increase, the demand for freshwater is approaching its limit (one-third of the global population now live in areas of "water stress"). In addition, increasing pollution from urban, industrial, and agricultural sources is making available resources either unusable or a major health risk. In the developing world, almost 5 million deaths per year are directly attributable to water-borne diseases, but an adequate supply of clean and safe water could prevent many of these deaths[2].

In the United Arab Emirates (UAE), fresh water is supplied in the form of ground water (obtained from wells)or desalinated water; however, the use of both is constrained. Desalinated water is expensive, and is produced using associated gas. The supply of ground water is limited by the total reservoir capacity within the country. These reservoirs are replenished by rainfall, which in the UAE is both scarce and erratic. In general, the requirements of industry and of people living in urban areas are met by 
the supply of desalinated water[12].Tap water, supplied in the form of desalinated sea water,is generally considered safe to drink, although the government's Food and Environment Laboratory does warn of the risk of contaminated water in buildings that have poorly maintained pipes [8].

Usually, domestic houses are fitted with two large water tanks: one is located at ground level and is filled with treated water, and the other is located on the roof and receives water pumped from the ground level tank. Both tanks supply the house with drinking water and water for cooking, washing clothes, showering, irrigation, fire suppression, and agriculture(plants and livestock). These tanks are often old and are not regularly cleaned or maintained, and therefore water quality is an issue. Although the demand for tap water in the UAE is increasing, the public must be aware of the consequences of poor quality water [21].
The Sharjah Electricity and Water Authority supply all regions of the Emirates with drinking water from both underground and desalinated sources. Modern desalination and production plants produce and treat both seawater and water from underground, which is then distributed to residential, commercial, and industrial consumers via transmission and distribution networks[17].

Worldwide, the microbiological content of water is tested to monitor and control both quality and safety. Such tests are undertaken to ensure that the water used for drinking, food preparation, and bathing is safe. Water contains many potential pathogens; therefore, it is impractical to screen all samples for all possible pathogens. Instead, several "indicator organisms" are used as surrogate markers of risk. Most water-borne diseases are caused by fecal pollution of water sources; therefore, the majority of tests aim to detect coliforms and E. coli[3].
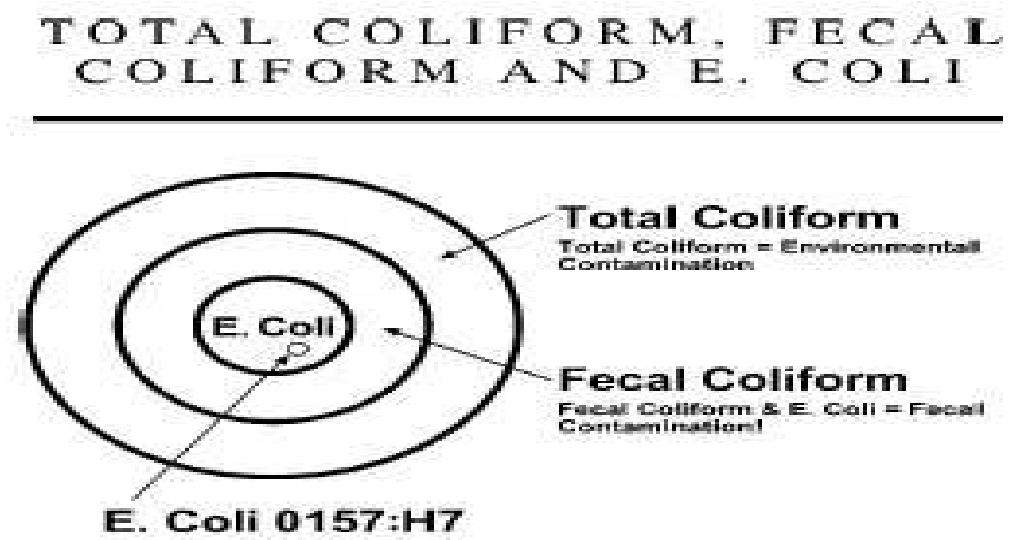

Source: Coliform Bacteria in Drinking Water (2011)

Figure 1. Groups of bacteria that are found in environment and/or intestinal tract of warm blooded animals and human.

There are three groups of coliform bacteria. Each is an indicator of drinking water quality and each carries a different level of risk. Coliform bacteria are common in soil and on vegetation, tend to live longer than pathogenic microbes [4], and are generally harmless; thus, they can be used as indicator organisms. For example, when coliforms are present in a sample of drinking water, it indicates that the source has been contaminated by surface water. The coliform test is considered a reliable indicator of the possible presence of fecal contamination, and the results correlate with the presence of pathogenic organisms[20].

Fecal coliform bacteria are a subgroup of coliform bacteria that are present in the intestines and feces of humans and animals. The presence of fecal coliforms indicates that a drinking water sample has been recently contaminated with feces and that there is an increased risk that it contains pathogens [7].

E. coliare a subgroup of fecal coliforms. Most E. coli reside within the intestines of humans and warm-blooded animals, and are harmless. However, some strains can cause illness. The presence of $E$. coli in a drinking water sample usually indicates recent fecal contamination, and therefore an increased risk of infection by pathogenic microbes[7].

Human and animal waste is a primary source of contaminating bacteria, which can enter the water supply via run-off from feedlots, pastures, and other land upon which animal waste is deposited. Natural soil and plant bacteria are also a potential source, along with seepage or discharge from septic tanks and sewage treatment facilities. Bacteria from these sources can also enter wells that are either open at the land surface, or do not have water-tight casings or caps [14]. Wells that are poorly constructed and, or, poorly maintained (particularly shallow wells) are at a high risk of contamination, allowing bacteria and other harmful organisms to enter the water supply[6]. Old wells dug by hand and lined (cased) with rocks or bricks usually have large openings and casings that often are not wellsealed. This makes it easy for insects, rodents or animals to fall into the well, providing a further source of contamination[14].

Infections and illness resulting from recreational water contact are generally mild; therefore, they are difficult to detect using routine surveillance systems. Even in cases of 
severe illness, it is difficult to identify contaminated water as the cause. Targeted epidemiological studies show that a number of adverse health outcomes, including gastrointestinal and respiratory infections, are associated with recreational water polluted by fecal matter [16]. Such adverse outcomes result in a significant disease burden and substantial economic losses [16].

The microorganisms that cause infection or disease depend upon the pathogen involved. It also depends on the circumstances in which the microorganism is encountered, the conditions of exposure, and the host's susceptibility and immune status. Indeed, in cases concerning viruses and parasitic protozoa, the dose may amount to no more than a few viable infectious units[20].

The quality of drinking water has a direct effect on the well-being of individuals at every social level. A report by the WHO attributed $4.0 \%$ of all deaths and $5.7 \%$ of the global disease burden to water-related illnesses, which stem from poor water quality, poor hygiene, and poor sanitation[15].These diseases disproportionately affect those in the developing world, particularly young children. In contrast to the developed world, less than half of subSaharan Africa has access to safe drinking water [19]. Infants are particularly susceptible to diseases caused by contaminated drinking water because they have not yet developed acquired immunity. Diarrhea, which is the major disease symptom caused by drinking contaminated water, accounts for 2.5 million deaths per year in children under5 years-of-age [11]. The aim of this study is to evaluate the quality of the water stored in storage tanks at Sharjah homes and compare with the quality of other emirates found from previous studies on Abu Dhabi and Al Ain.

\section{Methods}

Water samples were collected from the ground and roof top water storage tanks fitted in homes located in different regions in Sharjah. Triplicate samples were collected in 500 $\mathrm{ml}$ sterile bottles and shipped to the laboratory on ice. Two homes were sampled every week for six weeks. Microbiological analysis was performed using the MF technique, which isan effective and accepted method for testing fluid samples for microbiological contamination. The method involves less sample preparation than many traditional methods, and is one of the few methods that allow microorganisms to be isolated and counted quickly. The results are available within 24 hours.

Briefly, a sterile filter membrane was placed into a funnel assembly attached to a vacuum flask and the sample to be tested was poured in. The sample was filtered through the membrane under vacuum, thereby trapping any microorganisms present in the sample. The membrane filter was then removed from the funnel and placedonto an absorbent pad coated with prepared culture media. A pad coated with one ampoule of $\mathrm{m}$-Endo broth(Millipore) was used for the total coliform cultures, a pad coated with one ampoule of m-ColiBlue24 broth (Millipore)was used to culture E. coli, and a pad coated with one ampoule of trypticase Soy broth (Millipore) was used for the TBC. The pads and filters were then incubated at $35^{\circ} \mathrm{C}$ for $24 \mathrm{~h}$, and the number of colonies growing on each pad was counted. These steps were repeated for all triplicate samples and the average number of colonies per sample was calculated.

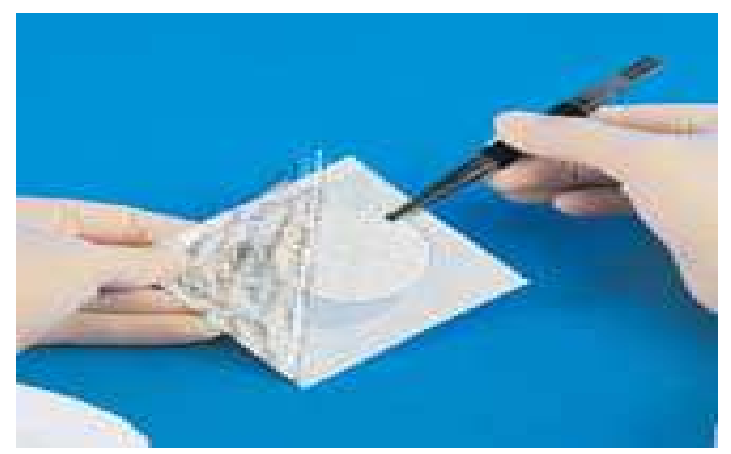

Fig.2. Remove the membrane from the sterile package.

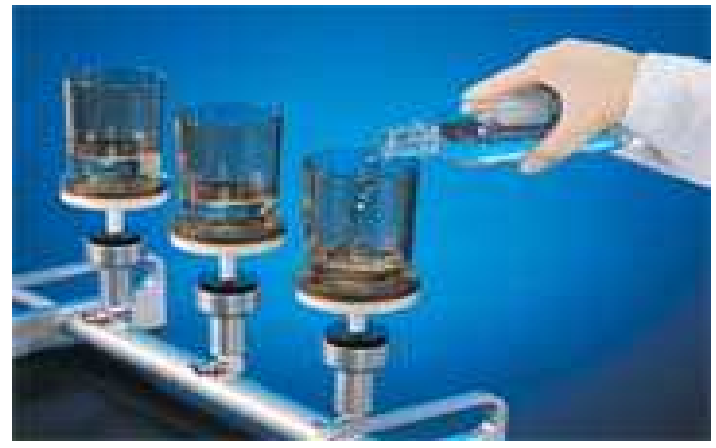

Fig. 3. Turn on the vacuum and allow the sample to pass completely through the filter.

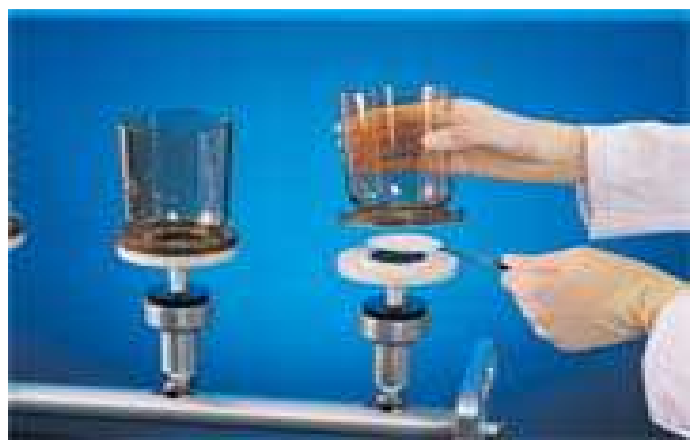

Fig.4. Remove the membrane filter from the funnel.

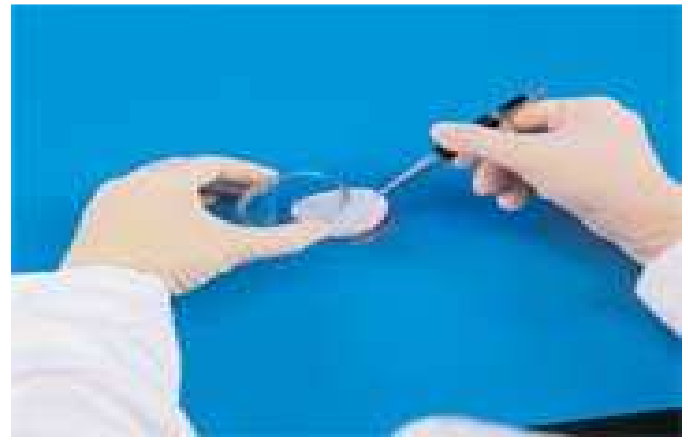

Fig. 5. Place the membrane filter into the prepared Petri dish. 


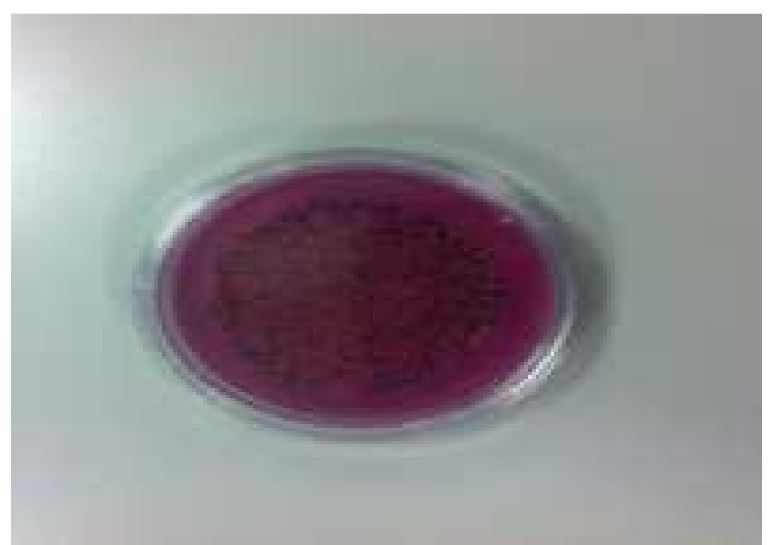

Fig. 6. The colonies are in red.

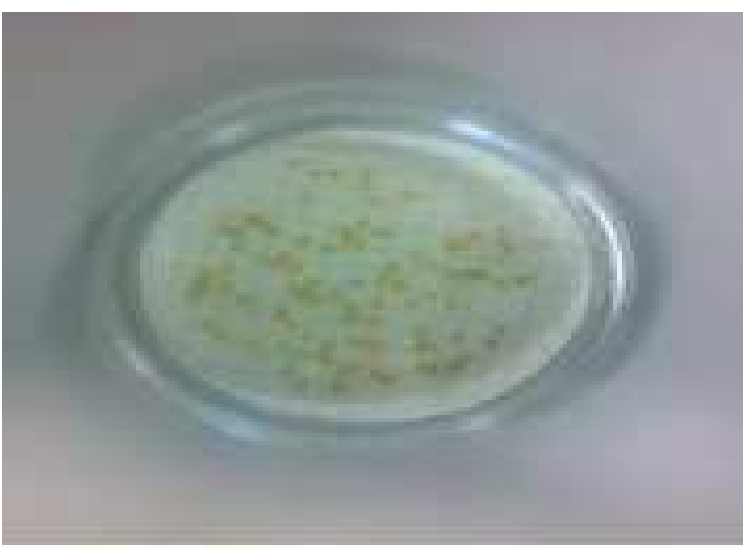

Fig. 7. The colonies are in yellow.

\section{Microbial Standards}

Table 1: Acceptable levels of bacterial contamination in the domestic water supply according to the Regulation and Supervision Bureau.

\begin{tabular}{lll}
\hline Parameter & $\begin{array}{l}\text { Units of } \\
\text { measurement }\end{array}$ & $\begin{array}{l}\text { Maximum } \\
\text { Prescribed Value }\end{array}$ \\
$\begin{array}{l}\text { Total Coliforms } \\
\text { E.coli or thermotolerent } \\
\text { Faecal coliform Bacteria }\end{array}$ & Number $/ 100 \mathrm{ml}$ & 0 \\
$\begin{array}{l}\text { Enterococci } \\
\text { Total Bacterial Count }\end{array}$ & Number $/ 100 \mathrm{ml}$ & 0 \\
$(37 \square$ C) & Number $/ 100 \mathrm{ml}$ & 10 \\
\hline
\end{tabular}

Source: The Water Quality Regulations. (2009). The Regulation and Supervision Bureau for the Water (Ed.). Abu Dhabi, UAE.

Table 1 show that the Maximum prescribed value for coliform bacteria in drinking water is zero (no coliforms detected in $100 \mathrm{ml}$ of water). It is sometimes difficult to count the number of coliforms and identify the individual species if excessive numbers of other bacteria are present. These samples may be classified as "too numerous to count" or as "confluent growth" [14].

\section{Analysis and Discussion}

In total, 22 samples from the ground (lower) and roof top (upper) tanks were collected and analyzed over a period of 2 months. As shown in Table 2, each sample was coded by a letter, which refers to the tank position (U, upper; L, lower), followed by the region in which the sample was collected, and a number that refers to the individual sample $(1,2$ or 3$)$ within a triplicate.

Table2. Sample details and test results

\begin{tabular}{|c|c|c|c|c|c|}
\hline Sample no. & Date of sampling & Location & Total coliforms [per $100 \mathrm{ml}$ ml & E.coli [per $100 \mathrm{ml}$ ] & TBC [per $100 \mathrm{ml}]$ \\
\hline LA1 & \multirow{3}{*}{$19 / 3 / 2012$} & \multirow{3}{*}{ Kalba - Al Musalla } & TFTC* & $\mathrm{BDL} \square$ & TFTC \\
\hline LA2 & & & TFTC & BDL & TFTC \\
\hline LA3 & & & TFTC & BDL & TFTC \\
\hline & \multirow{6}{*}{$19 / 3 / 2012$} & \multirow{6}{*}{ Kalba - Al Musalla } & - & - & - \\
\hline UA1 & & & TFTC & BDL & TFTC \\
\hline UA2 & & & TFTC & BDL & 28 \\
\hline UA3 & & & TFTC & BDL & 92 \\
\hline Average & & & - & - & 40 \\
\hline LB1 & & & TFTC & BDL & TFTC \\
\hline LB2 & \multirow[t]{2}{*}{$11 / 4 / 2012$} & \multirow[t]{2}{*}{ Kalba - Al Baraha } & TFTC & $\mathrm{BDL}$ & TFTC \\
\hline LB3 & & & TFTC & BDL & TFTC \\
\hline Average & \multirow{6}{*}{$11 / 4 / 2012$} & \multirow{6}{*}{ Kalba -Al Baraha } & - & - & - \\
\hline UB1 & & & 157 & BDL & TNTC $\dagger$ \\
\hline UB2 & & & 151 & BDL & TNTC \\
\hline UB3 & & & 200 & BDL & TNTC \\
\hline Average & & & 169.3 & - & - \\
\hline LK1 & & & TFTC & BDL & TFTC \\
\hline LK2 & $11 / 4 / 2012$ & Kalba -Alkhuwair & TFTC & BDL & TFTC \\
\hline
\end{tabular}




\begin{tabular}{|c|c|c|c|c|c|}
\hline Sample no. & Date of sampling & Location & Total coliforms [per100ml] ml & E.coli [per $100 \mathrm{ml}]$ & TBC [per 100ml] \\
\hline LK3 & \multirow{7}{*}{$11 / 4 / 2012$} & \multirow{7}{*}{ Kalba -Alkhuwair } & TFTC & BDL & TFTC \\
\hline Average & & & - & - & - \\
\hline UK1 & & & 178 & BDL & 203 \\
\hline UK2 & & & 202 & BDL & 219 \\
\hline UK3 & & & 194 & BDL & 210 \\
\hline Average & & & 191.3 & - & 210 \\
\hline LH1 & & & TFTC & BDL & TFTC \\
\hline LH2 & \multirow[t]{2}{*}{ 18/4/2012 } & \multirow[t]{2}{*}{ Kalba -Hutteen } & 92 & BDL & 121 \\
\hline LH3 & & & 55 & BDL & 73 \\
\hline Average & \multirow{6}{*}{$18 / 4 / 2012$} & \multirow{6}{*}{ Kalba -Hutteen } & 49 & - & 67 \\
\hline UH1 & & & 96 & BDL & 132 \\
\hline UH2 & & & 157 & BDL & 213 \\
\hline UH3 & & & 116 & BDL & 203 \\
\hline Average & & & 123 & - & 182 \\
\hline LZ1 & & & TFTC & BDL & TFTC \\
\hline LZ2 & \multirow[t]{2}{*}{$23 / 4 / 2012$} & \multirow[t]{2}{*}{ KhawrFakkan-Zubarah } & TFTC & BDL & TFTC \\
\hline LZ3 & & & TFTC & BDL & 118 \\
\hline Average & \multirow{4}{*}{$\begin{array}{l}23 / 4 / 2012 \\
23 / 4 / 2012\end{array}$} & \multirow{4}{*}{ KhawrFakkan-Zubarah } & - & - & 39.3 \\
\hline $\mathrm{UZ1}$ & & & TFTC & BDL & TFTC \\
\hline UZ2 & & & TFTC & BDL & TFTC \\
\hline UZ3 & & & 41 & BDL & 77 \\
\hline Average & \multirow{4}{*}{$30 / 4 / 2012$} & \multirow{4}{*}{ AlDhaid-Tawi Al Saman } & 13.6 & - & 25.6 \\
\hline LT1 & & & TFTC & BDL & TFTC \\
\hline LT2 & & & TFTC & BDL & TFTC \\
\hline LT3 & & & TFTC & BDL & TFTC \\
\hline Average & \multirow{4}{*}{ 30/4/2012 } & \multirow{4}{*}{ AlDhaid-Tawi Al Saman } & - & - & - \\
\hline UT1 & & & TFTC & BDL & TFTC \\
\hline UT2 & & & TFTC & BDL & TFTC \\
\hline UT3 & & & TFTC & BDL & TFTC \\
\hline Average & \multirow{4}{*}{$30 / 4 / 2012$} & \multirow{4}{*}{ Sharjah- Am Knorr } & - & - & - \\
\hline LN1 & & & TFTC & BDL & 42 \\
\hline LN2 & & & TNTC & BDL & TNTC \\
\hline LN3 & & & TFTC & BDL & TNTC \\
\hline Average & \multirow{5}{*}{$30 / 4 / 2012$} & \multirow{4}{*}{ Sharjah- Am Knorr } & - & - & 14 \\
\hline UN1 & & & TNTC & BDL & TNTC \\
\hline UN2 & & & TNTC & BDL & TNTC \\
\hline UN3 & & & TFTC & BDL & 102 \\
\hline Average & & & - & - & 34 \\
\hline LD1 & \multirow{3}{*}{$21 / 5 / 2012$} & \multirow{3}{*}{ Sharjah- Dibba Al Hosn } & 32 & BDL & 127 \\
\hline LD2 & & & TFTC & BDL & TFTC \\
\hline LD3 & & & TFTC & BDL & TFTC \\
\hline Average & \multirow{6}{*}{$21 / 5 / 2012$} & \multirow{6}{*}{ Sharjah- Dibba Al Hosn } & 10.6 & - & 42.3 \\
\hline UD1 & & & TFTC & BDL & TFTC \\
\hline UD2 & & & TFTC & BDL & TNTC \\
\hline UD3 & & & TFTC & BDL & 149 \\
\hline Average & & & - & - & 49.6 \\
\hline LY1 & & & TFTC & BDL & 34 \\
\hline
\end{tabular}




\begin{tabular}{|c|c|c|c|c|c|}
\hline Sample no. & Date of sampling & Location & Total coliforms [per $100 \mathrm{ml}] \mathrm{ml}$ & E.coli [per $100 \mathrm{ml}$ ] & TBC [per 100ml] \\
\hline LY2 & $21 / 5 / 2012$ & Sharjah-Al Yarmouk & 115 & BDL & TNTC \\
\hline LY3 & & & TNTC & BDL & TNTC \\
\hline Average & & & 38.3 & - & 11.3 \\
\hline UY1 & & & TFTC & BDL & TFTC \\
\hline UY2 & $21 / 5 / 2012$ & Sharjah-Al Yarmouk & TFTC & BDL & TFTC \\
\hline UY3 & & & TFTC & $\mathrm{BDL}$ & 33 \\
\hline Average & & & - & - & 11 \\
\hline LS1 & & & TFTC & BDL & TFTC \\
\hline LS2 & $27 / 5 / 2012$ & Kalba-AlSour & TFTC & BDL & TFTC \\
\hline LS3 & & & TFTC & BDL & TFTC \\
\hline Average & & & - & - & - \\
\hline US1 & & & TFTC & BDL & 70 \\
\hline US2 & $27 / 5 / 2012$ & Kalba-AlSour & TFTC & BDL & TFTC \\
\hline US3 & & & TFTC & BDL & TFTC \\
\hline Average & & & - & - & 23.3 \\
\hline LE1 & & & TFTC & BDL & TFTC \\
\hline LE2 & $27 / 5 / 2012$ & Sharjah- Al Kadesia & TNTC & $\mathrm{BDL}$ & TNTC \\
\hline LE3 & & & TNTC & BDL & TNTC \\
\hline Average & & & - & - & - \\
\hline UE1 & & & TFTC & BDL & TNTC \\
\hline UE2 & $27 / 5 / 2012$ & Sharjah- Al Kadesia & TNTC & $\mathrm{BDL}$ & TNTC \\
\hline UE3 & & & TNTC & BDL & TNTC \\
\hline Average & & & - & - & - \\
\hline
\end{tabular}

*TFTC: Too Few To Count

BDL: Below Detection Limit

$\dagger$ TNTC: Too Numerous To Count

Total Coliforms. The results showed that $5 / 11$ houses (45.4\%) met the total coliform standard(0 CFU/100ml). These samples (L/U: A, T, N, S, and K) were collected from Al Musalla (Kalba), TawiAlSaman (Al Dhaid), Am Knorr (Sharjah), Al Sour (Kalba), and Al Kadesia (Sharjah), respectively. Twohouses(18.1\%; L: D and Y) collected from Dibba Al Hosn (Sharjah) and Al Yarmouk (Sharjah), respectively, exceededthe standard. Both of these samples were taken from the lower tanks. The corresponding samples taken from the upper tanks did not exceed the standard counts. By contrast, threehouses (27.2\%; U: B, K, and Z) collected from the upper tanks in Al Baraha (Kalba), Al Khuwair (Kalba), and Zubarah (KhawrFakkan) exceeded the standard count. Samples taken from the corresponding lower tanks did not exceed the standard counts. One house $(9 \% ; \mathrm{L} / \mathrm{U}: \mathrm{H})$ out of the 11 collected from Hutteen (Kalba) exceeded the standard count in both tanks.

Total Bacterial count. The results showed that eight out of 11 analyzed samples exceeded the TBC standard count (10 CFU/100ml). Three houses (27.3\%; U: A, K, S) showed counts above the TBC standard in the upper level tank only. These samples were collected from Kalba- Al Musalla, Kalba- Al khuwair and Kalba- Al Sour, respectively. On the other hand, five other houses $(45.4 \%$; U/L: H, Z, N, D, and $\mathrm{Y}$ ) exceeded the TBC standard in both tank levels. These samples were collected from Kalba- Hutten, KhawrFakkan- Zubarah, Sharjah- Am Knorr, SharjahDibba AlHosn, and Sharjah- Al Yarmouk, respectively.

E.coli counts.None of the samples were positive for E.coli,suggesting the absence offecal contamination.

More than half of the samples $(54.5 \%)$ collected from storage tanks fitted to homes in Sharjah emiratewere positive for coliforms;however, none containedE.coli, althoughE.colican reproduce outside its natural environment (the intestine) [7]. Because both the global and local standard counts for coliforms and E.coliare $0 / 100 \mathrm{ml}$,their presencemeant that the water was unsafe for domestic use. This represents a clearrisk to public health, particularly in cases where people do not boil, filter or disinfect the water. It is important to determine the TBC to assess the safety of domestic drinking water. Furthermore, the absence of E.colidoes not mean that the water is notcontaminated byviruses or protozoa, which are more resistant to disinfection procedures[10].

The TBC is a national water quality standard and must not exceed $10 \mathrm{CFU} / 100 \mathrm{ml}$. Eight $(72.7 \%)$ of the water samples tested in this study exceeded this limit (U and/or L: A, K, H, Z, N, D, Y and S). Exceeding the standard is not an indicator of potential pathogenesis, as the count could 
include normal flora that do not pose a risk to human health. Therefore, it is necessary to identifythe species of bacteria present in water samples to make an accurate risk assessment.

There was a marked difference in theTBCbetween different areas within the same emirate, and between different tankswithin the same house.Bacterial growth is affected by a number of environmental factors, including temperature, $\mathrm{pH}$, salinity, and the availability of nutrients. Thus, bacterial counts may be higher in summer than in the winter.

Several water samples showed TFTC levels below the TBCstandard (10 CFU/100ml). The plate culture can underestimate the number of bacteria in the original sample because the harsh treatment involved may injure the cells, rendering them unable to grow on the plate. On the other hand, if non-coliformmicroorganisms are present in very high numbers, they may inhibit the growth ofcoliforms.

In general, tanks located at roof level showed higher bacterial counts (U: A, K, H, N, D and S). This is in agreement with the results of a similar study by Alkendi and Omer (2011), whichexaminedwater storage tanks in Abu Dhabi and Al Ain [1]. The higher level of contamination in the upper tanks may be explained by thefact that water is drawn from the bottom of the ground level tank and pumped into the upper tank, and therefore the water in the bottom of the lower tank may contain more bacteria, which settle to the bottom along with dust particles.

\section{Conclusion}

The MFmethod used in the current study to isolate and quantify bacteria has several advantages. The main advantage is that it is fast, yielding results within 24 hours of sampling. The rapid and accurate monitoring of microbes in drinkingwater is essential if we are to safeguard the consumer and improve water treatment and distribution systems.

For fast detection of water bacteria, the IDEXX technique is a breakthrough technology that delivers a fast, clear, visual color change that makes bacterial detection simple, without the need for culturing or colony counting, which can be subjective.

The pathogenicity of isolated bacteria can be assessed by gram staining of isolated bacteria.

Testing could also be improved by taking samples from different water columns within the same tank, which wouldprovide information about how the bacteria are distributed.

In most cases the quality of water deteriorates after it enters the storage tanks. The water in tanks is supposed to be safe to drink; however, we found that many tanks were contaminated with Coliform bacteria. Therefore, we recommend that the government and other relevant organizations in the UAE work to establish a comprehensive system to provide safe drinkingwater, which should include a robust household water supply, and provide related educational programs regarding hygiene.

In this case, water used for domestic purposes should be boiled, filtered, or disinfectedprior to use.Regular cleaning of tanks, along with appropriate protection, sealing, and maintenance, are highlyrecommended to ensure water quality. We recommend that families use appropriate filters to remove microorganismsfrom drinking water.Finally, a campaign should be instigated to raise public awareness and educate them about ways to protect and manage the quality of their water resources.

\section{References}

[1] Alkendi and Omer. (2011).Bacterial Quantification In Homes' Water Tanks. United Arab Emirates University, Faculty of Science, Biology department.

[2] Blacksmith Institute. (2012).Contamination surface water. New York, NY 10035 USA

[3] Barrell, Hunter, G Nichols.(2000). Microbiologicalstandards for water and their relationship to health risk.

[4] Bradley Scott.(2009). Total Coliform Bacteria.

[5] Coliform Bacteria in Drinking Water Supplies. (2011). New York State Department of Health, Retrieved 18 January 2012, Retrieved from http://www.health.ny.gov/

[6] Canada, Public Health Agency. (2011). Methodological Options of Source Attribution, Retrieved from http://www.phac-aspc.gc.ca

[7] Connecticut Department of Public Health.(2010).Presence of Total Coliform or FecalColiform/ E. coli Bacteria in the Water Supply.

[8] Dubai Electricity and Water Authority. (2012).Electricity and Water.Dubai Electricity and Water Authority,UAE.

[9] Guidelines for Water Reuse.(2004).U.S. Environmental Protection Agency. Washington EPA/625/R-04/108: Retrieved fromwww.epa.gov/

[10] Geneva.( 2008).Guidelines for drinking-water quality, third edition, volume 1 recommendation.

[11] Kosek M, Bern C, Guerrant R. (2000). The global burden of diarrhoeal disease Bull. World Health Organ. 2003;81(3):197-204.

[12] Moushumi Das chaudhury.(2005).UAE water consumption one of the highest in the world..Khaleej Times

[13] New Hampshire department of environmental service.(2010).Interpreting the Presence of Coliform Bacteria in Drinking Water.WDDWGB41.

[14] Oram B.(2012).Bacteria, Protozoans, Viruses and Nuisance Bacteria. Retrieved from Water Research Center website: http://www.water-research.net

[15] Prüss-Üstün A, Bos R, Gore F, Bartram J.(2008). Safer Water, Better Health, Costs,benefitsandsustainability of interventions toprotect and promote health. Geneva, World drinking-water. 
[16] Pruss A, Kay D, Fewtrell L, Bartram J.(2002). Estimating the burden of disease from water, sanitation, and hygiene at a global level. Environ. Health Perspect, 110(5):537-542.

[17] Sharjah Electricity and Water Authority:SEWA.(2008), Water Services.http://www.sewa.gov.ae/english/services/water.asp

[18] The Water Quality Regulations. (2009). The Regulation and Supervision Bureau for the Water (Ed.). Abu Dhabi, U.A.E.
[19] United Nations.(2005). Millennium Development Project Report

[20] WHO (2010).Optimizing regulatory frameworks for safe and clean drinking water, World Health Organization.

[21] Wait, I. (2008). Changing Perceptions: Water Quality and Demand In The United Arab Emirates. Paper presented at the 13th IWRA World Water Congress. 